\title{
The Realism And Relevance Of Regional Science\#
}

\author{
William H. MieRnYK*
}

Regional Science is the newest of the social sciences. The roots of regional economics-the precursor of regional science-can be traced to von Thünen's Der isolierte Staat, published in 1826. The birth of regional science as a separate discipline came much later, however. It can be dated rather precisely as December 27,1954 . This is when approximately sixty economists, geographers, planners, and others with an interest in spatial analysis, met to form the Regional Science Association [28]. The guiding light of this meeting was Walter Isard, the founder and still the prime mover of Regional Science.

The brief minutes of the first RSA business meeting indicate that it was far from clear that the new organization would survive. The general view appeared to be that the Association should make haste slowly. Even Isard "indicated that a skeleton type of organization would be adequate for most purposes [28]." The first volume of Papers and Proceedings was a mimeographed document. Some contributors to this meeting submitted abstracts only for inclusion in the Proceedings; they preferred to publish their complete papers elsewhere.

Twenty-two years later regional science is firmly established as an independent discipline with a broad international base. The January 1976 RSA Newsletter listed nineteen regional science journals or serials, and fourteen series of monographs, bibliographies, and reports. Today's regional science journals-including our own Review of Regional Studiesare able to attract articles that compare favorably, both from a methodological and a substantive point of view, with those of other professional societies.

Courses in regional science were offered until recently only at the university where Walter Isard happened to be teaching. Initially, this was MIT. Later Isard moved to the University of Pennsylvania where the first full-fledged department of regional science was established. Isard also started the Regional Science Research Institute which continues to function as an independent entity. The January Newsletter reports that fourteen universities are known to offer degree programs and specializa-

\#Presidential address delivered at the Annual Meeting, Southern Regional Science Association, Richmond, Virginia, April 8, 1976. My thanks for suggestions on an earlier draft go to Dr. Edward K. Smith, of the NBER, and to Professors Patrick Mann and Ming-jeng Hwang of WVU. Their willingness to be helpful does not necessarily imply agreement with all of the ideas expressed in this paper.

*Regional Research Institute, West Virginia University. 
tions in regional science today. In addition to those in the United States, such programs are located in Australia, Italy, Belgium, Germany, England, and Austria.

This brief recapitulation of events of the past two decades shows that regional science is now a firmly established discipline. Regional scientists know this, but it is not a fact that is widely known in the academic world; it is known even less in the world of practical affairs.

In part, the relative anonymity of regional science is simply a reflection of the newness of the discipline. But there are other contributing factors. First is the ambiguity that continues to surround the definition of regional science. In his recent Introduction to Regional Science, Isard gives thirteen definitions $[16, \mathrm{p} .5]$. Without any loss of generality, however, these definitions can be synthesized into one: Regional Science is the study of those social, economic, political, and behavioral phenomena which have a spatial dimension. ${ }^{1}$ But can all of these aspects of mankind's behavior be handled within the confines of a single discipline? Isard has long felt that they can [17].

In some respects Isard's vision of regional science is similar to that of Auguste Comte's vision of sociology. Comte believed that scientific thought would continue to evolve until it reached what he called "a positive stage" which would mark the end of scientific evolution. Comte grasped the notion that "knowledge in the various sciences is unified and related [22, p. 177]." And he felt that all of the strands of scientific thought would ultimately converge in a positive sociology. Comte clearly overestimated the capability of any scientist to keep abreast of developments in all fields. But he felt that at some point, perhaps in the distant future, there would be a single unified science. Similarly, Isard and his followers do not regard regional science as an interdisciplinary activity; it is a new, unified discipline.

Some members of regional science associations might question this characterization. This is because most of us who belong to regional science organizations have a dual identity. We are geographers and regional scientists; economists and regional scientists; planners and regional scientists, and so forth. Indeed, Charles Leven, whose contributions to regional science have been substantial, remarked in private conversation several years ago that at that time there was only one true regional scientist-Walter Isard.

The dual identity of regional scientists is easy to understand. Most of us came out of established disciplines, and most of us have spent our careers in traditional departments such as economics, city and regional planning, geography, and sociology. The early graduates of the first $\mathrm{Ph} . \mathrm{D}$. program in regional science also found employment in traditional departments. But as the number of regional science departments increases it is likely that a growing number of regional scientists will shed

\footnotetext{
1This differs from an earlier synthesis given in (24) which did not include the word "behavorial."
} 
their dual identity and will be known exclusively as regional scientists. This conclusion is predicated, of course, on the assumption that regional science will continue to evolve and to expand. Regional science should continue to evolve, of course, as part of mankind's general intellectual evolution. But the rate at which the discipline will grow depends, in my view, on the extent to which future "consumers" of education and research believe that regional science is a realistic discipline; one whose methods can be used to analyze issues of contemporary political, social, and economic concern. And this will happen, I believe, only if we and our students are able to avoid the methodological pitfalls of the other social sciences.

Since I am an economist in the other half of my joint identity, let me illustrate the point by reference to the field of economics. It is no secret that the present state of economics has been severely criticized from within by such luminaries as Leontief [20], Georgescu-Roegen [9], Galbraith [8], Boulding [15] and Baumol [1]. A recent issue of Fortune includes an article which illustrates a growing skepticism about the usefulness of contemporary economics as the latter is viewed from outside [2]. Economists also have been lampooned by journalists, including Art Buchwald and Russell Baker. I suspect that the hastily-written columns of the latter have more impact on the public mind than the combined lucubrations of those of us who labor in academic vineyards.

A quarter of a century ago, a typical issue of The American Economic Review would include several articles dealing with contemporary economic problems, one or two articles of a theoretical nature, and an occasional article on methodology. It was still considered proper to relegate mathematical discussion to an appendix, and while some articles included the kinds of graphs still found in intermediate textbooks, most were devoid of symbolic presentations. But Samuelson's Foundations of Economic Analysis had been published in 1947, and even before that he had started the stream of journal articles which only in recent years has shown any tendency toward abatement. While it might be unfair to attribute the dramatic change in the character of economic analysis that has occurred over the past quarter century to any one individual, I think few would quarrel with the statement that Samuelson's influence on modern neoclassical economics has been paramount [Cf. 34]. Today, a typical issue of The American Economic Review-or for that matter almost any economic journal-contains a high proportion of articles that have more to do with mathematics-complete with theorems, proofs, and lemmas - than with any recognizable economic issue. Many of those that are related to economic issues tend to be highly recondite, and in order to keep the mathematics tractable deal with the completely unreal world of "perfect competition" [on this, see Solo, 34, especially pp. 632-33].

Shortly before the trend leading to the present state of economics had been firmly established, Frank Knight, in his presidential address to the American Economic Association, had been led to wonder "whether econ- 
omists, and particularly economic theorists, may not be in the position that Cicero, citing Cato, ascribed to the augurs of Rome [the ancient Roman officials whose job it was to observe and interpret omens for the guidance of public affairs] - that they should cover their faces or burst into laughter when they met on the street [18, p. 2]." He felt that the published work of economists "must have some relation to the public interest if we are to expect public support; and why they pay us for it anyway is one of the deep economic mysteries . . . of popular economic irrationality [Ibid., pp. 4-5]." But Knight's evaluation had no apparent impact on subsequent events. His presidential address came at a time when most of the published work of economists dealt with problems and issues of contemporary concern. One cannot help wondering, however, if Knight did not have a clear intuition of what was to come.

A far more devastating methodological attack was leveled by Wassily Leontief, who received the 1973 Nobel Prize in Economics, in his presidential address. Leontief criticized the pretentious mathematical models which had come to dominate the pages of economic journals by the time he spoke. His qualms about these models were not caused by "the irrelevance of the practical problems to which present day economists address their efforts, but rather by the palpable inadequacy of the scientific means with which they try to solve them [20, p. 1]." "A typical theoretical model," he continued, "can be handled now as a routine assembly job. All principle components . . . come in several standard types; so does the optional equipment ..." Much of the discussion of these models consists of a "step-by-step derivation of its formal properties." The accuracy of these mathematical manipulations can generally be taken for granted. "Nevertheless, they are usually spelled out at great length. By the time it comes to interpretation of the substantive conclusions, the assumptions on which the model has been based are easily forgotten. But it is precisely the empirical validity of these assumptions on which the usefulness of the entire exercise depends [Ibid., p. 2]."

Leontief objects to the lack of realism in much of contemporary economics. He is not attacking the use of mathematics per se in economics. Indeed, anyone familiar with his own writings is aware that Leontief is an accomplished mathematician, and that his earlier publications in particular contain a great deal of involved mathematics. But to him mathematics has been a tool used to reach an analytical objective rather than an end in itself.

In the early 1950s when a growing number of journal articles were liberally sprinkled with equations, derivations, and proofs, some economists questioned the legitimacy of the application of rigorous analytical techniques to a discipline whose data consisted of relatively mushy estimates. Defenders of the new methodological approach pointed out that it has certain advantages. Properly done, it forces the analyst to write out his assumptions explicitly, and to carry through his analysis with logical rigor. By contrast, a purely verbal analysis can be bogged down 
in a semantic morass. Anyone who has waded through the voluminous growth pole-growth center literature will agree that this danger exists [6]. Thus the issue is not whether mathematics should or should not be used as an analytical tool. The issue is whether it will be used as a tool or-to use a felicitous term suggested by Heller-largely for "recreational purposes [15]." Baumol, another economist with impeccable mathematical credentials, has commented on this: "Elaborate superstructures are erected to show off spectacular applications of esoteric theorems with little regard for relevance or illumination. The writer indulges himself in what has been described by a great economist as illicit intercourse with beautiful models [1, p. 93]."

In his 1974 presidential address to the AEA, Walter Heller sought to redress what he considered to be an unbalanced view of the present state of economics. In the first section of his address he performed a useful function by succinctly summarizing the critical views of Galbraith, Leontief, and Boulding. He also summarized the criticisms made by other distinguished economists in their presidential addresses to a number of associations including the Econometric Society, Section F of the British Association, The Royal Economics Society, The Southern Economic Association, The American Finance Association, and the Eastern Economic Association. Most of his discussion, however, is devoted to an attempt to show "what's right with economics"- the title of his address.

Heller feels that "many competent, tough, and rigorously trained minds have been drawn into economics in response not just to challenging policy problems but to the quantitative revolution since World War II [15, p. 4]." These economists he tells us "can draw on a hard core of economic theory and methodology, together with a growing body of empirical knowledge, to provide standards for testing the validity (though not necessarily the relevance and reality) of ideas, analysis, and empirical findings [Ibid., emphasis added]." Heller tried to convince his listeners that modern economics has not only made major advances on the methodological and analytical fronts, but that it has become a highly useful discipline. I found his effort to be totally unconvincing. He mentions, of course, the successful 1964 tax cut as one instance in which the effects projected by economists corresponded closely to the subsequent. reality. But how long can economics continue to coast on a single successful application of a simple Keynesian model? One need not be an economist to be aware that other exercises in applied macroeconomics have not worked. Indeed, I have a feeling that one reason many economists prefer to deal with abstract exercises today is that they have nothing to say that would be even remotely interesting to those charged with the making and implementation of economic policy. And when public pronouncements are made by eminent neoclassical economists today they often refer to such parameters as the "appropriate" rate of growth or "desirable" unemployment rates and price increases. Such pronouncements require nothing in the way of analytical backup. 
The February 1976 issue of The Quarterly Journal of Economics is a case in point. The first 37 pages is devoted to a series of tributes to the late Alvin H. Hansen by a half-dozen of his former students and colleagues, including Paul Samuelson and James Tobin. Most commented on the pragmatic basis of Hansen's theorizing, and his lifelong preoccupation with the application of economic analysis to public policy. Above all else, Hansen was concerned with realism and relevance. To quote Samuelson: "Hansen did not regard economics as an ego trip. To him it was the fascinating study of how to improve the lot of humanity [33, p. 31]." Most of the remainder of this issue of the journal, however, is devoted to articles of the type that unequivocally fall under the heading of "mathematical recreation."

What can be said of regional science? Is there any more concern about reality among regional scientists than there is among mainstream economists? As it turns out, much of regional science $i s$ economics-regional economics. Thus, mutatis mutandis what has been said about economics could apply to regional science, and to some extent it does.

It is not hard to find examples of recreational mathematics in the regional science journals, particularly in recent years. But the basic orientation of most regional science research has been rather heavily empirical. Recently, for example, I asked two of my graduate assistants to classify all of the articles that have been published in The Journal of Regional Science to date. On the basis of their combined judgments, slightly more than six per cent of the pages of the leading regional science journal have been devoted to purely theoretical articles. Almost 42 per cent reported on empirical studies. It is significant, however, that articles dealing with policy issues accounted for fewer than five per cent of the pages. The subject matter of the remaining pages was distributed as follows: inputoutput analysis $(3 \%)$, linear programming models $(6 \%)$, interregional analyses, excluding input-output $(10 \%)$, growth models $(6 \%)$, central place theory and applications (15\%), and the description or application of other analytical tools ( $8 \%)$. Let me stress that there is a subjective element involved in this classification. But it is not likely that anyone else would arrive at a significantly different distribution of the content of articles under the same headings.

It would be interesting to see a similar content analysis of other regional science journals, and of the papers and proceedings of the annual meetings of various regional science associations. One might then be able to determine whether or not the trend in economics is being followed in regional science with an appropriate lag. There is limited evidence that it is if one compares the contents of Volume 35 of the RSA Papers with Volume one. But the kind of extreme abstraction found in most contemporary economic theory is still largely absent from the pages of regional science journals, and the proceedings of regional science association meetings. There is little in regional science, for example, to compare with the branch of contemporary economic theory which deals with capital and 
growth [14]. The mathematical models used to discuss the alleged behavior of the imaginary creatures who inhabit the one-product (putty, clay, or jelly) world of capital-growth theory make even some of the more abstract regional science models look highly realistic by comparison.

I have said that much of regional science is economics, but does this mean that all of contemporary regional economics fits comfortably under the regional science rubric? I feel that it does not. One area of considerable friction is that of regional growth theory.

Some economists, notably Borts and Stein, have applied neoclassical theory to the analysis of regional growth $[3,4]$. Richardson has been highly critical of the assumptions of full employment and perfect competition which are implicit in neoclassical regional models [30, p. 22]. He has developed an alternative theory of growth which emphasizes agglomeration economies and locational preferences-instead of the conventional neoclassical variables of wage and capital yield differentials. Borts feels that Richardson's model "winds up as an interesting, potentially testable, and useful synthesis of locational variables which might strengthen the neoclassical approach! [5, p. 546, emphasis added]." But he does not come to grips with the fundamental conflict between neoclassical theory and regional analysis pointed out earlier by Richardson. As Lösch made clear more than two decades ago, there is a basic incompatibility between spaceless neoclassical theory and location theory [21, especially pp. 105$30]$. As soon as space is explicitly introduced into an analysis-and this happens when agglomeration and locational preferences are taken into account-the assumptions of perfect competition no longer apply. At the micro level, the only model that is consistent with spatial analysis is that of monopolistic competition. Regional scientists are able to accept this; neoclassical regional economists are not.

Another part of the turf of regional science that has been "invaded" by conventional economists, with some resulting friction, is the broad area called urban economics. As might be expected, the invaders brought along their neoclassical analytical methods to produce what is referred to as the "new urban economics" in contrast to earlier studies which were more descriptive and policy-oriented [25, 26]. Once again Richardson took the offensive in a critical review of recent applications of simplified neoclassical models to complex urban problems with their explicit spatial dimensions [31, 32]. Richardson evidently succeeded in touching a sensitive nerve since one of the targets of his attack-Robert Solow-came back with a surprising ad hominem rejoinder. Part of the problem, Solow asserted, was that Richardson obviously had "never seen a real mathematical display! [35, p. 267]."

Regional science has little if anything to gain from attempts by mainstream economists to apply contemporary neoclassical theory to regional and urban problems. Up to the present, regional science has been more problem- and issue-oriented than conventional economics. And I would argue that it has been able to do this without sacrificing rigor. Space 
limitations preclude extensive documentation, but let me give a few examples.

The input-output model has been a favorite technique of regional analysts for almost twenty years. Many early regional and interregional input-output studies were exploratory, and hence had little practical value. But in the past ten years or so an increasing number of regional models have been carefully constructed from primary data, and have been successfully used for a variety of analytical purposes [10,23]. This is one of the few analytical techniques of which R. A. Gordon could speak kindly in his recent presidential address to the AEA. He feels that rigor and relevance "have been successfully blended" in input-output analysis [11, p. 3]. Increasingly, input-output models are being used extensively for state planning and other administrative purposes [7; 10, pp. 45-62]. Early input-output research at the regional level also led to a number of useful spin-offs such as Isard's industrial complex analysis [16].

There is a substantial and growing body of literature dealing with regional development problems and policies, both in the United States and abroad $[12,12,27]$. Regional development policy has not been a notable success either in the U.S. or in other parts of the world. But in this country it has been at least as successful as monetary, fiscal, manpower, and most international policies have been in achieving their stated objectives. The nexus between regional science and policy has been somewhat closer in Japan and Western Europe than in the United States [19]. But this is because some degree of economic planning is more widely accepted in most parts of the industrialized world than it is in this country. If, as some expect, the United States is slowly moving in the direction of indicative economic planning, the policy orientation of regional science will undoubtedly be strengthened.

In his review of Richardson's Regional Growth Theory, Borts was critical because: "The author gives no indication that interest in regional economics in the United States has declined substantially, and has been replaced by a study of the particular social and economic pathology of urban and rural areas [5, p. 547]." This is no doubt true; traditional economics journals probably contain a smaller proportion of regional articles than they did in the past. But this decline undoubtedly has been more than offset by the recent rapid expansion of regional science journals. Interest in regional economics-narrowly defined-might well be on the wane, but interest in regional science is clearly on the rise. Potentially, this could represent a net gain to society.

It should be obvious that I view regional science today as a more realistic discipline than the dominant branch of contemporary economics with its emphasis on neoclassical theory. It also is more relevant to current issues and problems than much of conventional economics. There is a tendency, however, for the newest of the social sciences to ape the older discipline from which it was derived. Since I agree with those who 
believe that modern neoclassical economics is involved in an ever-tightening spiral of trivilization, I do not regard this trend as a healthy one.

The trenchant criticisms of Knight, Leontief, Galbraith, Boulding, Georgescu-Roegen, and other giants of the profession, have had little impact on contemporary economics. Their criticisms have not been answered; they have simply been ignored. Why is this so? First, as Blackman has pointed out, "the profession's incentive system tends perversely to reward this kind of endeavor and to deflect the attention of gifted economists from the exploration of concrete problems and the dirty work that entails [15]." Galbraith provides part of the answer when he points out that business censorship, which was once a stultifying force in academic economics, has been replaced by a new despotism that consists in "defining scientific excellence as whatever is closest in belief and method to the scholarly tendency of the people who are already there $[8, \mathrm{p} .2]$." As long as those who control the system of rewards and the channels of publication in economics insist on maintaining the priority of a system of belief over reality it is likely that the drift away from realism and relevance, and toward increasing sterility, will go on. I sincerely hope that regional science will not continue its own slow drift in the same direction.

\section{REFERENCES}

1. Baumol, William J. "Economic Models and Mathematics." In The Structure of Economic Science, pp. 88-101. Edited by Sherman Roy Krupp. Englewood Cliffs: Prentice-Hall, Inc., 1966.

2. Beman, Lewis. "The Chastening of the Washington Economists." Fortune, January 1976, pp. 158-66.

3. Borts, G. H. and Stein, J. L. "Regional Growth and Maturity in the United States: A Study of Regional Structural Change." Schweizerische Zeitschrift für Volkswirtschaft und Statistik 98 (1962): 290-321.

4. Borts, George H. "Criteria for the Evaluation of Regional Development Programs." In Regional Accounting for Policy Decisions, pp. 183-218. Edited by Werner Z. Hirsch. Baltimore: The Johns Hopkins Press, 1966.

5. Borts, George H. Review of Regional Growth Theory, by Harry W. Richardson. Journal of Economic Literature 12 (June 1974): 546-47.

6. Darwent, D. F. "Growth Poles and Growth Centers in Regional Planning-A Review." Environment and Planning 1 (1969): 5-31.

7. Emerson, M. Jarvis. "Large Scale Models In Regional Development Planning." Regional Science Perspectives 4 (1974): 1-17.

8. Galbraith, J. K. "Power and the Useful Economist." The American Economic Review 63 (March 1973): 1-11.

9. Georgescu-Roegen, Nicholas. "Energy and Economic Myths." The Southern Economic Journal 41 (January 1975): 347-81.

10. Giarratani, Frank; Maddy, James; and Socher, Charles. Regional and Interregion- al Input-Output Analysis: An Annotated Bibliography. Morgantown: West Virginia University Library, 1976.

11. Gordon, Robert Aaron. "Rigor and Relevance in a Changing Institutional Setting." The American Economic Review 66 (March 1976) : 1-14.

12. Hansen, Niles M. Rural Poverty and the Urban Crisis. Bloomington: Indiana University Press, 1970.

13. Hansen, Niles M. Public Policy and Regional Economic Development. Cambridge: Ballinger, 1974.

14. Harcourt, G. C. "Some Cambridge Controversies in the Theory of Capital." Journal of Economic Literature 7 (June 1969): 369-405.

15. Heller, Walter W. "What's Right With Economics?" The American Economic Review 65 (March 1975): 1-26.

16. Isard, Walter. Introduction to Regional Science. Englewood Cliffs: Prentice-Hall, Inc., 1975.

17. Isard, Walter. Location and Space-Economy. New York: John Wiley \& Sons, Inc., 1956.

18. Knight, Frank H. "The Role of Principles in Economics and Politics." The American Economic Review 24 (March 1951): 1-29.

19. Konno, Genpachiro. "Prospects and Task of Regional Science in Developing Counties." The Regional Science Association. Papers. Chicago, Ill., November 1974, pp. 7-22.

20. Leontief, Wassily. "Theoretical Assumptions and Nonobserved Facts." The American Economic Review 61 (March 1971): $1-7$. 
21. Lösch, August. The Economics of Location. New Haven: Yale University Press, 1954.

22. Mazlish, Bruce. "Auguste Comte." The Encyclopedia of Philosophy. Volume 2. New York: Macmillan and The Free Press, 1967, pp. 173-77.

23. Miernyk, William $H$. "Regional and Interregional Input-Output Models: A Reappraisal." In Spatial, Regional and Population Economics, pp. 263-92. Edited by Mark Perlman, Charles Leven and Benjamin Chinitz. London: Gordon and Breach, Science Publishers, Ltd., 1973.

24. Miernyk, William H. Review of Introduction to Regional Science, by Walter Isard. Growth and Change (forthcoming).

25. Mills, E. S.; Mackinnon, J.; Solow, R. M.; Oron. Y.; Pines, D.; Sheshinski, E.; and Dixit, A. "Symposium on the New Urban Economics." The Bell Journal of Economics and Management Science 4 (Autumn 1973): 593-651.

26. Mirrlees, J. A. "Rejoinder to RichardsonII." Urban Studies 10 (1973): 267-69.
27. Newman, Monroe. The Political Economy of Appalachia. Lexington: Heath-Lexington Books, 1972.

28. Regional Science Association. Papers and Proceedings. Volume One (1955).

29. Regional Science Association. Newsletter. January 1976.

30. Richardson, Harry W. Regional Growth Theory. London: The MacMillan Press Ltd., 1973.

31. Richardson, Harry W. "A Comment on Some Uses of Mathematical Models in Urban Economics." Urban Studies 10 (1973): 259-66.

32. Richardson, Harry W. "Reply to Solow and Mirrlees." Urban Studies 10 (1973): 269-70.

33. Samuelson, Paul A. "Hansen as a Creative Economic Theorist." Quarterly Journal of Economics 90 (February 1976): 24-31.

34. Solo, Robert A. "Neoclassical Economics in Perspective." Journal of Economic Issues 9 (December 1975): 627-44.

35. Solow, Robert. "Rejoinder to RichardsonI." Urban Studies 10 (1973): 267. 